\title{
PYNSON'S CHAUCERS OF 1526: READING CUES AND READING PRACTICES
}

\section{Sean Gordon Lewis}

Reconstructing early readings of Chaucer's works is complicated business. While glosses in individual manuscripts and book copies may be windows into early interpretive communities, such glosses present limitations: much marginalia has been erased, and even the preserved marks of past readers may reveal idiosyncratic responses, rather than more general reading trends. Faced with such difficulties, careful study of the semiotic and rhetorical features of late medieval editions of Chaucer is a more reliable (though not infallible) method for understanding how Chaucer was read in Tudor England by attending to how his works were presented to be read. ${ }^{1}$ Unlike manuscripts, printed editions of Chaucer's works repeated patterns of layout, illustration, mis-en-page, and editorial text (prohemes, incipits, explicits, tables) in multiple book copies. ${ }^{2}$ Printed book copies are not as unique as their manuscript predecessors, and the interpretive choices made by printing houses are both the effects of and causes for reading methods and trends; a publishing house seeking to sell books would likely not present Chaucer's texts in ways that were completely at variance with the expectations of buyers and readers. The strategies for reading and interpreting presented by Tudor editions of Chaucer, then, provide a more stable basis for

\footnotetext{
${ }^{1}$ Of course, we cannot presume to recreate the reading habits of all readers of Chaucer within Tudor England. As Susan Reynolds notes in "Social Mentalities and the Cases of Medieval Skepticism," when reconstructing patterns of medieval thought, "It is probably a mistake to start with whole societies." Transaction of the Royal Historical Society, vol. 1 (1991), 40. My hope is that by grounding this study in more objective features of these editions, my case will avoid the historical assumptions she critiques. Furthermore, the medieval notion of texts as cues for the journey of the reader's mind has been well established by Mary Carruthers' work; see The Experience of Beauty in the Middle Ages (Oxford University Press, 2014) and "The Concept of Ductus, or Journeying through a Work of Art," in Rhetoric Beyond Words: Delight and Persuasion in the Arts of the Middle Ages, ed. Mary Carruthers (Cambridge: Cambridge University Press, 2010), 190-213.

${ }^{2}$ Rita Copeland has commented on the role of textual layout in Lollard pedagogy, indicating that such features of late medieval and Tudor books were part of the semiotic act of reading: "It is clear, however, that some texts were used to introduce readers, not to letters, but to relatively advanced exegetical practices, the mis en page of scriptural commentary, the difference between text and gloss, authentic text and exegetical authorities" (16-17). While Chaucer's texts are not, of course, as important to Tudor readers as Scripture, these habits of reading provide models for understanding how early editions of Chaucer encapsulate and encourage specific reading strategies. See Rita Copeland, Pedagogy, Intellectuals, and Dissent in the Later Middle Ages: Lollardy and Ideas of Learning (Cambridge University Press, 2001). This method of attending to non-linguistic features in these editions bears some similarity to Elizabeth Scala's notions of attending to the "work's unconscious," though without a directly psychoanalytical categories; see Elizabeth Scala, "Historicists and Their Discontents: Reading Psychoanalytically in Medieval Studies," Texas Studies in Literature and Language, vol. 44, no. 1 (Spring 2002): 108-131.
}

ENARRATIO 22 (2018)

(c) 2019 Lewis. This article is published under a Creative Commons AttributionNonCommercial-NoDerivatives 4.0 International License (https://creativecommons.org/licenses/by-nc-nd/4.0/) 
understanding early critical traditions of Chaucer than either manuscripts or marginalia. ${ }^{3}$

In terms of scholarly treatment of early editions of Chaucer, most studies have ignored the contributions of Wynkyn de Worde and Richard Pynson, choosing to focus on either Caxton's $15^{\text {th }}$-century editions or on the $16^{\text {th }}$ and $17^{\text {th }}$ century folio editions of Chaucer's complete works. ${ }^{4}$ The de Worde and Pynson editions of Chaucer, however, moreso than any other Chaucer printed in the remainder of the Tudor era, demonstrate and communicate the polysemy of Chaucer's poetry, and as such deserve further scholarly attention. At a minimum, the Chaucerian editions produced during the reigns of Henry VII and of Henry VIII before his "Great Matter" give its readers more "accessible" texts than those found in the folios, not overwhelming the reader with the monumental canonicity of the poetry. In their most striking cases, de Worde and Pynson produce editions whose editorial features, particularly woodcuts and commentaries, actually move readers towards complex reading strategies for Chaucer's works.

This study begins at the end, examining Richard Pynson's 1526 editions of Chaucer: The Canterbury Tales, Troilus and Criseyde, and The House of Fame anthology. This collection of Chaucerian works has most often been considered in relation to the folio Complete Works that followed it six years later; Pynson's editions are read as the first collected works of Chaucer, a precursor to Thynne's 1532 folio, or as an unintentional convergence of several works. ${ }^{5}$ I think that the story is more complicated. These three editions are bound together in all of the surviving book copies, but this fact reveals more about the book-collecting habits of antiquarians than it does about the original editions: while the Pynson Chaucers may be bound together to make an elegant whole, they are equally complete as

\footnotetext{
${ }^{3}$ My own treatment of readings and editions of Chaucer in this article was made possible by the research supported by the generosity of the National Endowment for the Humanities in their "Tudor Books and Readers" seminar of the summer of 2012 in Antwerp, London, and Oxford. I want to thank all of my colleagues who participated in the seminar; their feedback was crucial to the development of this article. In a special way, I thank John King and Mark Rankin, the directors of the seminar, who gave marvelous guidance and encouragement, as well as to Aaron Pratt, whose bibliographic advice was most helpful. My thanks goes out to Mark Rankin a second time for the suggestions he gave on a draft of this article.

${ }^{4}$ For Caxton, see Norman Francis Blake, "William Caxton," in Authors of the Middle Ages: English Writers of the Late Middle Ages, ed. M.C. Seymour (Brookfield, VT and Aldershot, Hants: Variorum, 1996), 1-68; William Kuskin, Symbolic Caxton: Literary Culture and Print Capitalism (Notre Dame, IN: Notre Dame Press, 2008); and Lotte Hellinga, William Caxton and Early Printing in England (London: British Library, 2010). For treatments of the folio editions of Chaucer, see Joseph A. Dane, Who is Buried in Chaucer's Tomb? Studies in the Reception of Chaucer's Book (East Lansing: Michigan State University Press, 1998); Kathleen Forni, The Chaucerian Apocrypha: A Counterfeit Canon (Gainesville: University of Florida Press, 2001); Alexandra Gillespie, Print Culture and the Medieval Author: Chaucer, Lydgate, and Their Books 1473-1557 (Oxford: Oxford University Press, 2006); Tim William Machan, "Speght's Works and the Invention of Chaucer", Text 8 (1995): 145-70; and Paul Ruggiers, ed., Editing Chaucer: The Great Tradition (Norman, OK: Pilgrim Press, 1984).

${ }^{5}$ Pynson's notoriety as an incompetent collector of Chaucerian works originated in D.S. Brewer's edition of Chaucer's Works: The Works 1532 with supplementary material from the Editions of 1542, 1561, 1598 and 1602 (London: Scholar Press, 1978), in which Pynson's Chaucers of 1526 were called "a half-hearted approach to a "complete works" (4). Since Brewer, further studies have sought to reevaluate Pynson and these editions; see Julia Boffey, "Richard Pynson's Book of Fame and the Letter of Dido," Viator 19 (1988): 339-53; Robert A. Foley, Richard Pynson's Boke of Fame And its NonChaucerian Poems: A Study and an Edition (D.Phil. thesis, Jesus College, Oxford, 1987); and Kathleen Forni, "Richard Pynson and the Stigma of the Chaucerian Apocrypha," The Chaucer Review 34, no. 4 (2000): 428-36.
} 
stand-alone items. ${ }^{6}$ Each of Pynson's last Chaucer editions has a unity unto itself; when the 1526 Pynsons are considered not as a miniature complete works, but as the last three editions of the period of individual Chaucerian works in print, they reveal the rich variety of strategies for presenting and interpreting Chaucer. The editorial structures of these editions reveal sets of reading cues: to discontinuous reading as a means of uncovering authorial intent in the case of The Canterbury Tales; to the application of universal truths in a Criseyde-centered Troilus and Criseyde; and to commonplace reading for moral edification in The House of Fame anthology. This last edition, in particular, is best understood in light of these reading strategies, and the current study hopes to correct some misconceptions about its paratextual features. By reproducing and circulating a variety of reading strategies, Pynson's editions have left us with a tantalizing picture of ways in which Chaucer was read at the beginning of the sixteenth century.

\section{The CANTERbury TAles: CAXTONiAn TRADitions}

Richard Pynson published his first Chaucerian work, an edition of The Canterbury Tales, in 1492 (STC 5084). Up to that point, Caxton had been the only printer of Chaucer's works, but with his death new printings from other houses began to appear. In preparing the novelty of the first non-Caxtonian Chaucer in print, however, Pynson's house did not meddle with success: the 1492 Pynson Canterbury Tales is, by and large, a close reproduction of Caxton's 1483 edition (STC 5083). The woodcuts are of a different character. Pynson had to have a new series cut, since de Worde inherited Caxton's house and obviously kept the woodcuts for the Tales, using them six years later for his 1498 edition. ${ }^{7}$ Despite the difference in physical appearance, however, Pynson's woodcuts are used in a manner similar to the 1483 Caxton. They are positioned in the same places in the text (for the most part) and function mnemonically: while some of the cuts illustrate fairly well the characters portrayed, most of them are stock illustrations of pilgrims, functioning as aids for textual navigation, a pictorial index. ${ }^{8}$ Pynson's 1526 edition of The Canterbury Tales (STC 5086), however, does show significant differences from the 1492 in terms of type (bâtarde), layout (double columns), and frequency of illustrations (no pilgrim woodcuts in the General Prologue). These changes keep the book within the Caxtonian tradition of Canterbury Tales editions, while using less than half the amount of paper necessary to print the former folio edition. ${ }^{9}$

\footnotetext{
${ }^{6}$ In fact, the binding of these works actually suggests that they be considered separately, since the order in which they are bound varies; the British Library's copy is ordered House of Fame, Troilus and Criseyde, then The Canterbury Tales, while the University of Glasgow's is ordered Canterbury Tales, Troilus and Criseyde, House of Fame. I want to thank Robert MacLean of the University of Glasgow's Library for his assistance with this detail.

${ }^{7}$ See David R. Carlson, "Woodcut Illustrations of the Canterbury Tales, 1483-1602" The Library, Series 6, 1, no. 1 (1997): 25-67.

${ }^{8}$ Images were, of course, used mnemonically throughout the Middle Ages, placing Pynson's use of these woodcuts in a long tradition; Mary Carruthers's The Book of Memory, $2^{\text {nd }}$ ed. (Cambridge: Cambridge University Press, 2008) is a classic study of this phenomenon.

${ }^{9}$ Even by a very rough sheet estimate, the 1526 Pynson edition uses significantly less paper than the 1492 edition, containing approximately 60 leaves of paper versus approximately 150 leaves.
} 
Such a combination of frugality and imitation of the tradition should not, however, lead one to consider the 1526 Canterbury Tales to be simply a derivative, cheap version of editions past; editorial features of this book-most significantly its table of contents - distinguish it from its predecessors, making it a contribution to Chaucerian printing and reading in its own right. The edition's title page is an innovation in the presentation of the Tales: Caxton, of course, did not use title pages, and de Worde's title page of 1498, despite gaining the honor of being the first Chaucerian title page in history, was a simple affair of seven words in the center of an otherwise blank page: "The boke of Chaucer named Caunterbury tales." By contrast, Pynson's title page is relatively elaborate (Fig. 1). ${ }^{10}$ The title itself proclaims its difference from previous Tales by using an old Caxtonian trope of correction (familiar in critical editions to this day!): "Here begynneth the boke of Canterbury tales / dilygently and truely corrected / and newly printed." The diligence and truth of such "corrections" is dubious, as it is asserted in every sixteenth-century edition of Chaucer; nevertheless, the edition makes a claim for itself as a critical improvement over past editions. Beneath the title, surrounded by a double border of stock elements (flowers, kings, birds, Christological symbols), the reader encounters the very first illustration to appear on a Canterbury Tales title-page.

That Pynson's house chose to put a woodcut on the title-page is not surprising; such a practice was common by the 1520's, and is found in Pynson's other two Chaucers of 1526. What is perhaps surprising is the choice of woodcut: the title page of the Canterbury Tales presents the reader with a portrait of the Squire - the same woodcut used in Pynson's 1492 edition and reused before the Squire's Tale in this edition (G.iii. ${ }^{\mathrm{r}}$ ). The identity of the Squire is unmistakable, this cut being one of the pictures that more clearly illustrates the character: the Squire wears a jaunty hat, has long, flowing locks (curled, as in his description), and holds an arrow, apt metonymy for a young man concerned with courtly love and the influence of Cupid. It would be wrong to read too much careful attention into this feature of the title-page; perhaps the compositor, in preparing the page, simply found the Squire's woodcut the most convenient. Still, its semiotic value does privilege the tales of courtly romance; a Canterbury Tales led by the Parson would have quite a different effect on framing the work as a whole.

The verso side of the title page also reveals a slight shift in Chaucerian presentation in the form of the Proheme. Caxton's Proheme to the Tales was the first item in Pynson's 1492 Canterbury Tales, but with the rather cheeky subtitle, "By Richard Pynson" in place of "By William Caxton." This could, of course, simply refer to Pynson's status as publisher of the work, but, in a less charitable interpretation, does displace Caxton in the history of Chaucerian printing. De Worde may have read it in exactly this manner, since his 1498 Tales gives underneath the Proheme, "By William Caxton / His soule in heuen won," restoring the status of his master. De Worde also highlights Caxton's status in the Canterbury Tales by including a woodcut of Caxton before his Proheme. While this might be taken to be simply a random pilgrim serving as an initial illustration for the tales, de Worde tended to be careful with his woodcuts. ${ }^{11}$ The same

\footnotetext{
${ }^{10}$ HEW 5.11.8, Houghton Library, Harvard University; image used with permission.

${ }^{11}$ Seth Lerer argues that de Worde was careful in his selection of woodcuts for his Troilus and Criseyde, and presumably the same care was shown in other Chaucer editions. See "The Wiles of
} 
woodcut is also used in this edition for the Merchant. Significantly, Caxton was a member of the mercer's guild, and he never once referred to himself in writing as a "printer," self-identifying as a merchant until the end of his life. ${ }^{12}$ These features strongly suggests that de Worde inserted Caxton as the first pilgrim encountered in the Canterbury Tales, a mediating voice delivering the Proheme before the reader encounters Chaucer, whose woodcut - repeated before Chaucer's Talecomes immediately before the beginning of the General Prologue on the next leaf. ${ }^{13}$ Pynson's 1526 edition takes a less audacious approach, simply giving under the Proheme, "Thus endeth the proheme." Removing Caxton from the Tales may seem like a small move, but it has profound rhetorical implications: while the edition retains the traditional Caxtonian proheme, it does not call attention to itself as an authoritative part of the Tales. Caxton's name and face disappear from Pynson's 1526 Canterbury Tales and remain absent in all the subsequent early modern editions of Chaucer's text.

The editorial apparatus applied to the Tales themselves further reveals an apparently intentional move on the part of Pynson's house to give editorial instructions that suggest the practice of discontinuous reading for the purpose of ascertaining Chaucer's authorial intent. Discontinuous reading — reading back and forth across sections of a work, rather than from cover to cover-was not, of course, an unusual practice in the period; this was a normal way to read the Bible, and the apparatus of printed Bibles - marginal glosses, chapter divisions, and, eventually, verse divisions - encouraged readers to engage the text as a collection of interconnected pieces, rather than a continuous narrative from the first to the last page. ${ }^{14}$ Particularly if read typologically, a Bible read in this fashion would reveal something of the intent of the author, what God was apparently communicating through the Word. Pynson's 1526 Canterbury Tales certainly does not have as complex an apparatus as a Bible; its pages are mostly free from the editorial intrusions of a modern critical edition, giving the readers their own margins to fill in if they will. ${ }^{15}$ What it does have, however, are small innovations in textual presentation that more easily allow the reader to approach the work as

Woodcut: Wynkyn de Worde and the Early Tudor Reader," The Huntington Library Quarterly 59, no. 5 (1996): 381-403.

${ }^{12}$ Norman Francis Blake, "William Caxton," in Authors of the Middle Ages: English Writers of the Late Middle Ages, ed. MC. Seymour (Brookfield, VT and Aldershot, Hants: Variorum, 1996), 1-68, 33.

${ }^{13}$ Inserting oneself into the Canterbury Tales was not a revolutionary concept in the $15^{\text {th }}$ century; apocryphal tales were circulated, and Lydgate's Siege of Thebes presents the author as one of the Canterbury pilgrims.

${ }^{14}$ Peter Stallybrass, "Books and Scrolls: Navigating the Bible," in Books and Readers in Early Modern England: Material Studies, ed. Jennifer Anderson and Elizabeth Sauer (Philadelphia: University of Philadelphia Press, 2002), 42-79.

15 The British Library's copy of Pynson's 1526 Canterbury Tales is almost entirely free of sixteenth-century reader response, with a few notable exceptions. At the woodcut of the feast of the Canterbury pilgrims (A.vir; Hodnett 151), there appears, in a sixteenth-century hand: "vos omnes comprece [ ] doest impeche us" (the page has cut off part of the notation). There are three instances of simple word repetition: "freeres" next to the woodcut of the Friar; "The pryores tale" in the scroll of the Prioress's woodcut; and "Chaucer" at the penultimate page of the Tale of Chaucer. There is but one manicule in the copy, pointing out the following lines of the Wife of Bath's Prologue: "And trewly / As my husbande tolde me / I had the best queynte that might be." Such were the priorities of one of the early readers of this book copy. 
a collection of distinct tales rather than as a continuous narrative, combined with subtle nods to authorial intention.

In the first place, immediately following the Proheme is the first table of contents in the history of The Canterbury Tales: "here foloweth the names of them that tell the tales." The reader is given a dramatis personae list, which also indicates the order of the tales themselves. ${ }^{16}$ Even though it does not point the reader to the pages on which these tales may be found (as the tables of contents in the folio Chaucers will do), it does provide an initial tool for readers to move around in the text, finding more easily those tales in which they are interested. Readerly interest is tied to authorial intent by the incipit to the General Prologue, which loudly proclaims Chaucer's authorial status: "The prologue of the auctour in whiche he maketh mencyon; howe and where this company met / and of there condycions, and array / and what they be: As ye shall se herafter" (A.iir). ${ }^{17}$ This incipit cues readers to the details they should look for in reading: the setting and occasion of the pilgrimage and storytelling competition, as well as the characters themselves: their states, their appearances, and "what they be." ${ }^{18}$ Pynson's 1526 edition points out that Chaucer- "the auctour"-is giving these details for some significant reason, and it gives its readers a list of characters and indexical woodcuts to allow them to navigate easily back and forth through the tales to compare those details given by the author in the prologue with the prologues and tales of the characters themselves.

Chaucer's authorial presence is further stressed by subtle shifts in textual presentation later on in the edition, beginning with its treatment of Chaucer's Ryme of Sir Thopas and Tale of Melibee. Pynson's 1526 edition follows the practice in the 1483 and 1492 editions of repeating the woodcut of Chaucer before both of these tales; de Worde's 1498 edition gives a single woodcut of Chaucer

\footnotetext{
${ }^{16}$ The ordering of the tales in Pynson's 1526 edition is curious. Both of Pynson's editions follow the order of Caxton's 1483 edition: Fragment 1 (A), Fragment $2\left(\mathrm{~B}^{1}\right)$, The Merchant's Prologue and Tale (Fragment 4, Group E, second tale), Fragment 5 (F), Fragment 3 (D), The Clerk's Prologue and Tale (Fragment 4, Group E, first tale), Fragment $8(\mathrm{G})$, Fragment $6(\mathrm{C})$, Fragment $7\left(\mathrm{~B}^{2}\right)$, Fragment 9 (H), Fragment 10 (I). De Worde's 1498 edition differs from his master Caxton, reuniting Fragment 3 and placing it in the same order as the Ellesmere Manuscript, though keeping Caxton's placement of Fragment $8(\mathrm{G})$ before Fragments 6 and 7. This likely shows some attention to correction on De Worde's part, without undertaking a wholly new edition based on a manuscript. Caxton also prints Chaucer's Retraction; Pynson omits this feature in his 1492 edition, but restores it in 1526. De Worde's 1498 edition does not include the Retraction, as we shall see. My reading of Pynson's 1526 edition, then, is that Pynson returned to the Caxton 1483, going back to the first "corrected" Caxton, rather than correcting Caxton's text, as de Worde did.

${ }^{17}$ After Barthes, Derrida, and Foucault, the concept of "authorial intent" is somewhat taboo in discussions of literature. Given the centrality of the author in this edition, however, it appears as though sixteenth-century readers were rather less anxious over such matters, and if Chaucer was supposed to instruct and delight them (telling "tales of best sentence and moost solaas," Canterbury Tales 1(A) 798), an editor might well want to point out the details mentioned by "the auctour." By "authorial intent" I mean precisely these textual details. Given the setting and the characters found in The Canterbury Tales, the 1526 edition encourages readers to decode the meaning behind the text, the meaning that Chaucer, presumably, intended to give for the reader's instruction.

${ }^{18}$ As with the ordering of the tales, Pynson's use of incipits and explicits follows Caxton closely. This practice is particularly evident in the treatment of unfinished tales, using The Squire's Tale as a salient example. Caxton simply prints: "Ther is nomore of the squyers tale / The wordes of the frankeleyns" (p1 $\left.1^{v}\right)$. This is the exact treatment followed in Pynson's $1492\left(\mathrm{q}^{\mathrm{r}}\right)$ and $1526\left(\mathrm{~g} 6^{\mathrm{v}}\right)$. De Worde differs somewhat, returning to the trope of correcting previous text: "There can be founde no more of this forsayd tale. Whyche I haue right diligently serchyd in many dyuers copyes" $\left(\mathrm{m}^{\mathrm{r}}\right)$. De Worde again shows signs of corrections against manuscripts, while Pynson is content to copy Caxton.
} 
before the Tale of Melibee. The repetition of woodcuts gives clear authorial presence both in the jangling parody of a metrical romance and in the sententious prose tract; this is a marked change from the Chaucer portraits in major manuscripts of the Tales, which present Chaucer only next to the Tale of Melibee, "authorizing" the serious tale alone. ${ }^{19}$ Chaucer the comedian and Chaucer the sage thus share status in the center of Pynson's edition. Ultimately, though, the 1526 Pynson Tales do privilege the serious Chaucer as the final impression left with the reader. The explicit to the Parson's Tale repeats Caxton's trope from 1483, attributing the Parson's Tale directly to Chaucer: "Explicit tractatus Galfridi Chaucer de Penitentia vt dicitur pro fabula rectoris" ("Here ends the treatise of Geoffrey Chaucer on Penitence, as it was said through the tale of the rector," Y.iii ${ }^{v}$ ). Even though these tales are told through various pilgrims, the editorial apparatus does not let the reader forget that Chaucer is the author speaking behind them all; all of these tales are messages from Chaucer, as spoken in the stories of various characters, characters whose individual features are highlighted at the very beginning of the edition. This authorial presence closes the edition; the final item in the 1526 Tales is Chaucer's Retraction (Y.iiiv). Caxton printed this Retraction in 1483; Pynson's 1492 and de Worde's 1498 editions omit it. The presence both of the "vt dicitur" and the Retraction shows that it is highly probable that the 1526 edition was, in fact, corrected against a copy of Caxton's 1483 edition, ${ }^{20}$ but more importantly ends the work by instructing the reader on Chaucer's intentions in writing the tales: "all that is written / is written for our doctrine / and that is myne entent." Twenty-first century readers may find the Retraction to be rather tongue-in-cheek, "repenting" of writing certain works while conveniently naming them for the reader, giving an authorized canon by denying the value of some of the works included. Given the other features of the 1526 edition, however (the focus on details of explicitly authorial origin and a handy list of characters to serve as a table of contents), this Retraction is given as direct reading instructions: Chaucer is telling us how to read the tales, and Pynson's printing house is giving us the tools to perform this reading: reading across the tales, comparing tales to the General Prologue, and trying to decode the authorial intent behind this disparate collection. ${ }^{21}$

\footnotetext{
${ }^{19}$ The Ellesmere Manuscript (Huntingdon Library MS EL26 C9) contains the famous Chaucer portrait pointing to his name at the beginning of Chaucer's Tale/The Tale of Melibee, and MS. Rawl. Poet 223 at the Bodleian Library also contains a Chaucer portrait in the initial capital of the Tale. Helen Cooper has noted that mis-en-page in surviving manuscripts do call visual attention to the humor of Sir Thopas ("Chaucerian Representation," 22), but the use of authorial portraits before the Tale of Melibee puts the authorial weight on the latter tale rather than the former. See Helen Cooper, "Chaucerian Representation," in New Readings of Chaucer's Poetry, ed. Robert G. Benson and Susan J. Ridyard (D.S. Brewer: Cambridge, 2003), 7-30.

${ }^{20}$ Given the relative paucity of changes, correction against Caxton versus a manuscript is the likely explanation; see footnote 16 of this article.

${ }^{21}$ In this way, the 1526 Pynson Canterbury Tales may give new credence to D.W. Robertson's approach in A Preface to Chaucer (Princeton: Princeton University Press, 1962); even if critics think that Chaucer should be read for more than Christian moral teaching, the fact of the matter is that in the sixteenth century Chaucer was presented to be read for Christian moral teaching.
} 


\section{TROILUS AND CRISEYde: Universal PATtERns OF LOVE}

Turning from The Canterbury Tales to Troilus and Criseyde, Pynson's edition of Troilus and Criseyde presents readers with editorial patterns that depict a decidedly positive vision of Criseyde and move readers to consider the universal patterns of love. To appreciate Pynson's achievement fully, however, we must first briefly consider de Worde's edition of the text (1517, STC 5095), to which Pynson is directly responding. While the Caxton Troilus and Criseyde is a fairly "open" edition with very little presence of editorial cues, de Worde broke with his master's design by inserting two explicit interpretive features: a series of woodcuts and a presumably "authorial" epilogue. ${ }^{22}$ The woodcuts of de Worde's edition are worthy of their own study, having been carefully chosen to focus the reader on Troilus and his suffering at the hands of the false Criseyde. Though one could devote a study to these woodcuts as a whole, I will mention two here that are particularly illustrative. The initial and final woodcuts depict the pledge (engage-ment) between Troilus and Criseyde, which, working with the other woodcuts and book titles, highlights the fact that Criseyde breaks this pledge. Yet De Worde keeps the focus on Troilus throughout this edition in his introductions to the books. Book 2 introduces the reader to Criseyde, but for de Worde's edition, the Troilus-Pandarus relationship is highlighted in the title: "Consequently foloweth the secunde boke of Troylus / and it sheweth how that Pandare vncle of Creseyde / dyde the message of Troylus vnto Creseyde as foloweth" (fol. D1 ${ }^{\mathrm{r}}$. Book 3 is the most joyful part of the text (governed, as it is, by Venus in Chaucer's invocation, 3.1-21), but de Worde's introduction prompts the reader to attend only to Troilus's complaint: "The secunde boke fynysshed here begynneth the thyrde and sheweth how that Creseyde came to Troylus and of the right piteous complaynte of Troylus as foloweth" (fol. $\mathrm{J} 1^{v}$ ). De Worde's opening for Book 4 is less concerned with Troilus's feelings, but does highlight the tragic irony of Antenor (ultimate betrayer of Troy) being exchanged for Criseyde: "Now this my fourte boke sheweth how that the Imbassatoures of Grece came to Troye for Creseyde / and of the grete sorowe that Troylus and Cresyde made whan they herde that Antynor shoulde be delyuered beynge prisoner and Cresyde rendred for the aquytaunce of hym" (fol. $N 7^{r}$ ). Book 5 firmly orients the reader to Criseyde's betrayal of Troilus: "This my laste boke of Troylus consequently foloweth / and sheweth how that Cresyde fell to the loue of Dyomede / and he vnto her love / and how she forsoke Troylus after her departynge out of Troye / contrary to her promise" (fol. S3 ${ }^{v}$ ). All of these editorial features promote a reading of the text centered on Troilus and his plight, and the woodcut illustrations before each book—generic images intelligently recycled—reinforce de Worde's text.

Most significantly, however, de Worde ends his edition with a three-stanza rhyme royal postscript entitled "The auctour," which is about as misogynistic a reading of Troilus and Criseyde as is possible:

And here an ende / of Troylus heuynesse

As touchynge Cresyde / to hym right vnkynde

${ }^{22}$ Jackson Campbell Boswell and Sylvia Wallace Holton, Chaucer's Fame in England: STC Chauceriana 1476-1640 (New York: Modern Language Association of America, 2004), 25. 
Falsly forsworn / deflouryng his worthynes

For his treue loue / she hath hym made blynde

Of feminine gendre / the woman most vnkynde

Dyomede on her whele / she hathe set on hye

The faythe of a woman / by her now maye you se

Was not Arystotle / for all his clergye

Vyrgyll the cunnynge / deceyued also

By women inestimable / for to here or se

Sampson the stronge / with many a .M. mo

Brought in to ruyne / by woman mannes fo

There is no woman / I thynke heuen vnder

That can be trewe / and that is wonder

O parfyte Troylus / good god be thy guyde

The moste truest louer / that euer lady hadde

Now arte thou forsake / of Cresyde at this tyde

Neuer to retourne / who shall make the gladde

He that for vs dyed / and soules frome hell hadde

And borne of the vyrgyne / to heuen thy soule brynge

And all that ben present / at theyr latre endynge.

$\operatorname{AMEN}\left(\mathrm{Z7}^{\mathrm{v}}\right)^{23}$

The Christological reorientation is inspired by the canonical palinode (5.18071869) and ending of Troilus and Criseyde - even keeping the final "Amen"-but, significantly, this misogynistic attitude is completely opposed to the narrator's view of Criseyde (5.1093-99). Ignoring the words of Chaucer's narrator, the cavalier misogyny at the end of de Worde's edition indicates a response to and a continuation of an anti-feminist reading of the work. ${ }^{24}$ It would be very odd indeed for de Worde to publish an interpretive cue that was utterly out of line with popular readings of the work, and the fact that he felt comfortable enough to put these words into Chaucer's own mouth seem to indicate some degree of popularity in this interpretation; the edition indicates that this is the sentence to be gleaned from the story. Indeed, when such an epilogue is reproduced and circulated in

\footnotetext{
${ }^{23}$ Here is the text with modernized punctuation and spelling: “And here an end of Troilus' heaviness / As touching Crisedye, to him right unkind, / falsely forsworn, deflowering his worthiness. For his true love, she hath made him blind. / Of feminine gender, the woman most unkind [Fortune], Diomede on her wheel she hath set on high. / The faith of a woman by her now may you see. / Was not Aristotle for all his clergy, / Virgil the cunning, deceived also / By woman inestimable, for to hear or see? / Sampson the strong, and many a thousand more / Brought in to ruin by woman, man's foe? / There is no woman, I think, heaven under / That can be true, and that is wonder! / O perfect Troilus, good God be thy guide, / The most truest lover that every lady had. / Now art thou forsaken of Cresyde at this tide, / Never to return. Who shall make thee glad? / He that for us died, and souls from hell had, / And born of the Virgin. To heaven thy soul bring / And all that be present at their later ending."

${ }^{24}$ Further evidence for the lack of direct misogyny in Chaucer's narrator (and even a warning against the untruth of men) may be found in Book 5: "Bysechyng every lady bright of hewe / And every gentil woman what she be / That al be that Criseyde was untrewe / That for that gilt she be nat wroth with me / Ye may hire gilt in other bokes se / And gladlier I wol write yif yow leste / Penolopees trouth and good Alceste / N'y sey nat this al oonly for thise men / But moost for women that bitraised be / Thorugh false folk - God yeve hem sorwe, amen! / That with hire grete wit and subtitle / Bytraise yow. And this commeveth me / To speke, and in effect yow alle I preye, / Beth war of men, and herkeneth what I seye!" (5.1772-85).
} 
multiple book-copies, it does, in effect, promote this "authorial" reading of the poem. Even though de Worde's edition runs contrary to Chaucer's own narrator, it provides clear evidence for an interpretive community sympathetic to Troilus' plight and utterly unconcerned with Criseyde.

In contrast to de Worde, Richard Pynson's use of woodcuts in his 1526 edition supports the narrator's more sympathetic reading of Criseyde, while also suggesting that readers attend to the universal nature of the love story beyond its particulars. Although Pynson's Troilus and Criseyde imitates de Worde's in its use of woodcuts, the semiotic frame they present is quite different from that of the de Worde edition. These illustrations are copies of woodcuts found in Gerard Leeu's edition of William Caxton's translation of Pierre de la Cépède's Paris and Vienne ("Thystorye of the right noble and worthy knight parys and of the fayre vyenne the dolphins doughter of vyennoys"), printed in Antwerp in 1492 (STC 19207). The woodcuts in Leeu's English edition of this story were first used in the Leeu 1487 edition of the French original, Histoire du Chevalier Paris et de la belle Vienne. ${ }^{25}$ Pynson's copies of these woodcuts are actually in many ways superior to the originals found in Leeu's book; they retain the compositional and structural features of Leeu's cuts while giving greater detail. Their technical superiority aside, they are, however, clearly reused woodcuts, ${ }^{26}$ and even a reader unfamiliar with Leeu's Paris and Vienne could recognize this fact by the many extraneous detials. ${ }^{27}$

These woodcuts are not, however, reused in a haphazard fashion. They have been selected to pair intelligently with the action of Chaucer's Troilus and Criseyde, and in doing so focus the reader on the general application of the story through a curious focus on specific textual details. While Pynson's 1526 Canterbury Tales pointed readers to close, discontinuous readings of textual details to establish authorial purpose, Pynson's 1526 Troilus and Criseyde moves readers to follow the narrative structure of the story, communicated through images, while attending to the more universal experiences represented in the poem. The scenes depicted in the woodcuts are close enough to serve as illustrations for Troilus and Criseyde, and this feature moves the reader to recognize the generic nature of such a love story-scenes from one love story are more or less interchangeable with scenes from another, suggesting that romantic love tends to follow predictable, stereotypical courses. This is not to suggest, of course, that all loves end like Troilus and Criseyde's love; on the contrary, the

${ }^{25}$ William Martin Conway, The Woodcutters of the Netherlands in the Fifteenth Century (Cambridge: Cambridge University Press, 1884), 248-9.

${ }^{26}$ Hodnett does not note the origins of these cuts in the Low Countries, identifying the first cut (Hodnett 1933) as part of the "Bevys of Southhamptowne" series (so called because Pynson also used it to in his circa 1503 edition of that work), and the rest as the "Paris and Vienne" series, without reference to the woodcuts' original provenance (387). See Edward Hodnett, English Woodcuts, 14801535 (Oxford University Press, 1935).

${ }^{27}$ To my knowledge, there are no book copies of the Pynson Troilus and Criseyde that show marginalia linking it to Leeu's Paris and Vienne. As far as paratextual indications of Leeu's influence on Pynson, there seem to be none: while both books are printed in double columns, Paris and Vienne uses batarde type to set prose, while Troilus and Criseyde uses Blackletter to set verse. Furthermore, the incipits in Paris and Vienne are topical (for instance, "How parys wan the prys at the joustes in the cyte of Parys," Bi $\mathrm{i}^{\mathrm{r}}$ ) while the incipits in Troilus and Criseyde are linked to chapters ("Here begynneth the prologe of the first boke"; "Thus endeth the prologe," A.iir). 
surprisingly sympathetic picture of Criseyde these illustrations produce suggests the hope that other love stories might end more happily.

The first woodcut in this edition is found on the title page, under a title that already brings to mind the truth to be sought in this work: "Here begynneth the boke of Troylus and Creseyde / newly printed by a trewe copye" (A.i ${ }^{\text {r }}$ (Fig. 2). ${ }^{28}$ "Trewe" here obviously means an authoritative exemplar, but the word choice is significant. The last printed edition of Troilus and Criseyde made much of the truth of Troilus and the untruth of Criseyde, and the question of truth is certainly central to the poem. Under this proclamation of truth, the reader finds, surrounded by generic borders, a scene composed of three people: a lordly man, a lady, and a smaller lady, standing indoors with a window in the background looking out at a country setting. The composition of this illustration is reminiscent of the title page illustration for the de Worde 1517 edition, where the focus is on the two grown figures, and the man's left hand is reaching out towards the lady - these two are easily read as Troilus and Criseyde. What, however, of the third, smaller woman? In the 1492 Leeu Parys and Vienne, this scene appears on the title-page and is clearly a depiction of Vienne's family: the Dauphin, his lady, and Vienne as a young girl. ${ }^{29}$ When grafted on to Troilus, however, the young girl's presence is semiotically complex, highlighting the social dimension of the story. While the de Worde edition focused solely on the relationship between the two title characters, the Pynson edition includes an onlooker who could be read as a servant, one of Criseyde's female friends, or even one of her children: "But whether that she chylde had or none / I rede it nat / therefore I late it gone" (1.13233; A.ii v). The fact that Pynson's text reads "chylde" instead of the now-accepted "children" may indicate that Pynson or one of his compositors made a decision that the narrator of the poem passes over, portraying Criseyde as a widowed mother on the title page. Regardless of how the smaller woman is identified, she is present; the story of Troilus and Criseyde does not take place outside of a social context, and this social context will continue to be stressed in the woodcuts that follow. This image of Criseyde, true to the text (even if taken from another), governs and colors the reader's image of Criseyde in Book I, beginning an editorial depiction of the story that is, in contrast to the de Worde edition, fundamentally sympathetic to her plight.

The second woodcut, found at the beginning of Book II (B.ii $\left.{ }^{r}\right)$, depicts the meeting of two lovers in a church: the man approaches from the right, the woman from the left, and they hold a ring between them; an altar stands in the background. Troilus and Criseyde's initial encounter takes place at the Temple of Pallas (148$280)$; the cut is intelligently chosen to comport with the details of Chaucer's story. The final detail of this illustration, however, is the two lookouts on either side of the couple: a woman to the left of the lady looks over her shoulder, as though keeping watch; a man to the right of the gentleman is gazing on the scene. In the context of the story for which this woodcut was made (C. $v^{v}$ in Leeu's edition), this makes sense: Paris is departing from Vienne after having placed her in a

\footnotetext{
${ }^{28}$ HEW 5.11.8 , Houghton Library, Harvard University; image used with permission. Given spatial constraints, I have chosen to reproduce in the appendix only those images that I find most significant in this edition. All of these editions are, of course, on Early English Books Online.

${ }^{29}$ William Martin Conway, The Woodcutters of the Netherlands in the Fifteenth Century (Cambridge: Cambridge University Press, 1884), 248-49.
} 
sanctuary to keep her safe from her father's interference. The Pynson cut is a mirror image of Leeu's, but the action is the same, and in Paris and Vienne lookouts-Isabel and Edward - are certainly necessary as the lovers try to remain undetected by the Dauphin. A similar sense of secrecy prevails in Troilus and Criseyde: they keep their love a secret, even though they are brought together by a third party. This outside frame of the love story - the ladies who are unaware of Criseyde's love (Book IV.673-730) and Pandarus, who looks on the two lovers he brings together - continues to be placed in the foreground at the beginning of Book II. ${ }^{30}$

Before Book III, the Pynson edition presents its most fascinatingly specific reuse of a woodcut: the image shows, on the left, a man lying in bed attended by a woman, and on the right a separate room containing two women: one is holding a vessel, the other three banners, each of which has "vienne" written on it (D.iiv). Initially, the right-hand scene may make this image seem like a rather unintelligent choice for Book III of Troilus and Criseyde: the women and banners (won by Paris in a tournament) are clearly out of place in the action of the story. Nevertheless, if a compositor were cannibalizing Paris and Vienne for illustrations, this scene is actually a fitting choice: Pandarus' plan to couple Troilus and Criseyde in Book III relies on Troilus lying sick in bed (2.1513-1526). A major detail in this scheme is the use of separate rooms in a house: Pandarus's plan to bring the lovers together sexually depends on Troilus remaining hidden in another room during Criseyde's visit (3.600-2). While details in the scene on the right are extraneous, the fact that the illustration is bicameral keeps perfectly with the details of Book III, and the scene of a man in bed visited by a woman is a good fit for the narrative, while reminding readers that even the most private of romantic scenes is not far from the eyes or ears of others.

By Book IV, the reader has come to expect a good thematic fit between the clearly reused illustrations and the text, and this book, in which the Greek embassy takes Criseyde from Troy back to the Grecian camp, begins with an illustration well suited to the actions described (F.iv. ${ }^{r}$ ). The Pynson woodcut is, again, a mirror image of the original, and Leeu's illustration occurs before the following chapter: "How parys with two freres went into Alexandrye where he was worshypfully recyued of Thadmyrall" (e.iir). This is exactly what is shown in the woodcut. In the Pynson copy, three men in friars' habits congregate near a city gate to the right of the scene. In the center, a man presents a letter bearing a seal to a man dressed in foreign garb, with pointed hat and scimitar (in Paris and Vienne, the Turkish admiral). Behind the admiral, another man in foreign clothing - the jailer - looks towards a house, out of which a man is peering, as though exiting or hiding (in Paris and Vienne, it is the Dauphin imprisoned). A fountain with a statue is in the lower left foreground. The general elements of this very specific scene are again appropriated to the action of Book IV: a man in European garb presents a letter to a foreign man. The letter is presumably the "treaties" between the Greeks and Trojans for the exchange of prisoners (4.5770), presented to King Priam of Troy by Calchas, in the company of "lordes olde" (4.66). The man peeking out of the doorway, witnessing the action but not

\footnotetext{
${ }^{30}$ On the relationship between texts and the absent texts surrounding them, consider Elizabeth Scala's Absent Narratives: Manuscript Textuality and Literary Structure in Late Medieval England (New York: Palgrave, 2002).
} 
partaking in it, can be interpreted as Troilus: "This Troylus was present in the place / Whan asked was for Anthenore Creseyde / For whiche full sone changed he his face, / As he that with tho wordes full nygh deyde / But nathelees he no word to it seyde" $\left(4.148-52 ; \mathrm{F} . \mathrm{v}^{\mathrm{r}}\right){ }^{31}$ The outer world, which has always been present visually in Pynson's edition, now steps in to jeopardize their love: Criseyde is bargained back to the Greeks, while Troilus looks on silently.

The final illustration occurs before Book V, depicting a scene that solidifies the sympathetic treatment of Criseyde presented in this edition (H.v $\mathrm{v}^{\mathrm{r}}$ (Fig. 3). ${ }^{32}$ Identical in its elements to Leeu's original, the woodcut depicts a woman kneeling down to a lord at the gates of a city. The gentleman in the gate appears to be inclined to reject the woman's plea: he turns his head away in aversion, even though he is looking at her. Two men stand behind her-one a tonsured cleric, one a layman - and are gesturing towards her. To the left, a man on horseback holds the reigns of the lady's horse; a tower stands the background. This woodcut appears twice in Leeu's Paris and Vienne: once on folio c.iiij ${ }^{\mathrm{r}}$, heading the chapter, "How the daulphin dyd doo serche and serche vyenne by his seruauntes" and again on folio c.vir $i^{r}$, heading the chapter, "How vyenne was founde in the chyrche by a foteman: and how she was brought ageyn to hyr fader." In the original context, the scene clearly depicts the Dauphin's servants bringing Vienne back to her father: "whan vyenne was comen tofore hyr fader the daulfphyn he made to ward hyr heuy and euyll chere But not withstondyng vyenne kneled doun on bothe hyr knees to the erthe" (c.vi $\left.{ }^{\mathrm{v}}\right)$. In the context of Troilus and Criseyde, however, the image focuses the reader on Criseyde's powerless status at the end of the poem. Criseyde has been returned, on horseback, to the Greeks, and is pleading before them and her father Calchas. While a reader familiar with Henryson's Testament of Cresseid might see the scene in a different light - the whorish and diseased Criseyde placed before a disdainful Troilus - readers in the 1520 's had yet to encounter the Testament in print, and had only to turn to the story for the situation: Criseyde obediently returns to her father, leaving Troy in the background. ${ }^{33}$ As with the other illustrations, this is a fitting depiction of the action of the book, and is striking for the fact that it does not focus attention on Troilus at the end, but on Criseyde; rather than the double sorrow of Troilus, Pynson's 1526 edition moves the reader to consider the sorrow of Criseyde, both at the beginning and at the end.

It is now clear that, even while using recycled woodcuts, the program of illustration for Pynson's Troilus and Criseyde is thoughtfully constructed, seeking to match illustrations to scenes from the text, constructing a set of interpretive directions sympathetic to Criseyde. ${ }^{34}$ In so doing, Pynson's house put together a

\footnotetext{
${ }^{31}$ Throughout this article, I have given the text as it is printed in the Tudor editions, while using the line numbers found in The Riverside Chaucer. Differences do exist, obviously, between these texts and the readings given in the Riverside edition, but they are mostly insubstantial.

${ }^{32}$ HEW 5.11.8, Houghton Library, Harvard University; image used with permission.

${ }^{33}$ There is no exact date for Henryson's Testament of Cresseid, but Henryson's death around 1500 places it before the end of the fifteenth century. The first printed instance of the Testament is in Thynne's 1532 edition of the Workes, where it immediately follows Troilus and Criseyde, beginning with an incipit that overtly links it to the previous work: "Thus endeth the fifth boke and last of Troylus: and here foloweth the pyteful and dolorous testament of fayre Creseyde" (fol. ccxii ${ }^{v}$ ). There are no surviving printed editions before 1532, and only partial witnesses survive in manuscripts.

${ }^{34}$ While we cannot be certain whether Pynson himself had a hand in the choice of which available woodcuts to use, it is likely that as the master printer he would have overseen the pattern of illustration.
} 
series of illustrations that do more justice to the story than perhaps any other series available. ${ }^{35}$ The implications for how Troilus and Criseyde is presented to be read by this edition turn on the recycled quality of its illustrations. As we have seen, this edition focuses the reader on the action of the poem, paying attention to details that are pertinent to the story itself, with a special focus on Criseyde and the social context in which the lovers' story takes place. Still, while the illustrations are close enough to do justice to Chaucer's work, they contain enough extraneous details to let the reader know that they are derived from another love story. The alterity of the illustrations is key: the reader knows that these scenes are from a different tale, but they are applicable to the action of Troilus and Criseyde. The story has universal resonances, and it points to more general truths about human love. While Pynson's edition omits de Worde's misogynistic advice at the end, it implies that general lessons may, in fact, be drawn from its pages. What these specific lessons are, of course, depends on the reader; the Pynson Troilus and Criseyde is an edition more open to reader response than de Worde's, even as it silently focuses the reader on Criseyde and the social dimension of the plot. The Pynson Troilus and Criseyde, then, is an edition that beautifully attends to Chaucer's words and embodies the complexities of the tragedy, giving readers general lessons that may be applied to other romantic situations.

\section{The House of Fame: VirTuous Reading PRACTICES}

As we have seen, Pynson's Canterbury Tales is more or less a copy of Caxton, and his Troilus and Criseyde a unique and provocative contribution to the presentation of Chaucer's most popular work in the English Renaissance. ${ }^{36}$ Pynson's House of Fame anthology is a much more difficult edition to make sense of. In the first place, this edition is a collection of a variety of different works: Chaucer's House of Fame; Chaucer's Parliament of Fowles; Richard Roos's La Belle Dame sans Mercy (attributed here to Chaucer); Chaucer's “Truth"; Christine de Pizan's Moral Proverbs; the anonymous Complaynte of the louer of cryst Saynt mary Magdaleyn; the anonymous Letter of Dydo to Eneas; and Lydgate's "Consulo Quisquis Eris" ("Proverbs of Lydgage"). Such a collection is not, of course, utterly surprising; Caxton had printed an anthology of shorter Chaucerian works beginning with the Parliament of Fowles (called "The Temple of Brass," STC 5091), and manuscript anthologies of shorter Chaucerian works are common enough, such as MS Bodley 638, MS Tanner 346, and MS Fairfax 16 (the socalled "Oxford Group"). If towards the end of his career Pynson was returning to his earlier practice of copying Caxton, an anthology including The Parliament of Fowles was a natural enough choice. More important than the fact that this is an

For the role played by the master printer in determining book illustrations, see John King, Foxe's Book of Martyrs and Early Print Culture (Cambridge: Cambridge University Press, 2006); Karen Bowen and Dirk Imhof, Christopher Plantin and Engraved Book Illustrations in Sixteenth-Century Europe (Cambridge: Cambridge University Press, 2008); and Elizabeth Evenden, Patents, Pictures and Patronage: John Day and the Tudor Book Trade (Farnham, U.K.: Ashgate Publishing, Ltd., 2008).

${ }^{35}$ As fun as Eric Gill's erotica in the margins of the 1932 Random House Troilus and Criseyde may be ("Englished anew" by George Philip Krapp; New York: Random House, 1932), it rather cuts against the central tragic action of the poem; Gill's illustrations are more appropriate for Pandarus' randy imaginings than Troilus's swoons or Criseyde's fears.

${ }^{36}$ Alice Miskimin, The Renaissance Chaucer (New Haven: Yale University Press, 1975), 169. 
anthology, however, is the apparent opacity of the principle of selection. Set next to the carefully executed editions of 1526, the House of Fame anthology could easily be considered an afterthought, an attempt to bundle together shorter works of Chaucer with other various medieval poems to make a book long enough to attract customers and turn a profit. Such a mercantile motive for the edition may well account for many of its oddities, yet this anthology demonstrates some of the same care found in Pynson's Canterbury Tales and Troilus and Criseyde. Close examination of the features of this edition and the contents of the poems reveals that there are, in fact, clearly discernible principles of selection. The Pynson House of Fame anthology is an edition that overtly prompts its readers to commonplace it, gleaning what moral instruction they can from its diverse contents. $^{37}$

In laying out the evidence for this anthology as a collection of moral sentence, I should begin by addressing a prevalent misreading of the title-page woodcut as a direct illustration of Chaucer's House of Fame. ${ }^{38}$ Hodnett considers the woodcut to be an image of "Dame Rumour as a queen . . . [which] illustrates the Boke of Fame with unusual effectiveness," and Gillespie follows Hodnett by giving an extended reading of this image as directly Chaucerian: "[A]ll of these texts follow from a single, controlling image, a unique title-page woodcut that depicts Fame as she appears in Chaucer's House of Fame: a queen who adjudicates literary endeavours. She holds out two banners beneath the 'sterres seven' that light her court on which are lozenges - the distinctive form of escutcheons bearing the heraldic insignia of unmarried noble or armigerous gentlewomen." 39 The title-page woodcut, however, is by no means a picture of "Fame as she appears in Chaucer's House of Fame." The image, framed by a border similar to that of Pynson's Canterbury Tales, shows a crowned woman standing on the seven-headed dragon from the Book of Revelation (Fig. 4). ${ }^{40}$ To her right and left are multitudes of people: to her right (reader left) is a crowd containing a knight, a king, and an anthropomorphic lion; to her left (reader right) is a crowd containing a knight, a well-dressed gentleman, and an anthropomorphic wolf-like beast. The lion is stabbing the beast with a spear. The woman is facing the army on her left, and extends over both of them squares on which are set five

\footnotetext{
${ }^{37}$ For more on reading as a process of personal improvement, see Brian Stock, "The Self and Literary Experience in Late Antiquity and the Middle Ages," New Literary History 25, no. 4 (Autumn 1994): 839-52. Stock notes directly that in medieval reading practices, "the result is not a text but an improved person" (844).

${ }^{38}$ Reading the title-page illustration in this way is often linked to feminist readings of the anthology; see Robert A. Foley, Richard Pynson's Boke of Fame And its Non-Chaucerian Poems: A Study and an Edition, D.Phil. thesis, Jesus College, Oxford, 1987, 153. While the anthology may support feminist readings, if such readings assume the title-page to be a straight-up House of Fame illustration, they are built on rather shaky foundations.

${ }^{39}$ Hodnett, 46; Alexandra Gillespie, Print Culture and the Medieval Author: Chaucer, Lydgate, and Their Books 1473-1557 Oxford English Monographs (Oxford: Oxford University Press, 2006), 129.

${ }^{40}$ Hodnett numbers this illustration 1500, and gives the following description: “(c) A queen standing on the back of a many-headed serpent, its heads at the left. In each hand she holds a piece of paper (?), on which are lozenge designs. Seven stars above each hand. (L) A crowned lion, standing upright holding a spear. (back) A multitude including a soldier and a king. (R) A crowned wolf (?), also upright. (back) A multitude" (346-7). Perhaps Gillespie's identification of what this female figure is holding as "lozenges" (and their subsequent tie to armigerous unmarried women) derives from this description. HEW 5.11.8, Houghton Library, Harvard University; image used with permission.
} 
diamonds - they look rather like books with metal bosses on their covers. Over each of these squares are seven stars. Even a cursory glance at The House of Fame shows that this is nowhere near Chaucer's description of Dame Fame:

But al on hye vpon a dees

Satte on a se emperyall

That was made of Ruby royall

Whiche a carbuncle is ycalled

I sawe perpetually ystalled

A femynine creature

That neuer formed by nature

Suche another thyng I saye

For altherfyrst, sothe for to saye

Me thought that she was so lyte

That the length of a cubyte

Was lenger, than she semed be

But thus soone in a whyle she

Her self, tho wonderly streyght

That with her fete she therthe reyght

And with her heed, she touched heuyn

There as shyneth the starres seuyn

And therto yet, as to my wytte

I sawe as great a wonder yet

Upon her eyen to beholde

But certainly, I hem never tolde

For as fell eyen had she

As fethers vpon foules be

Or weren on the bestes four

That goddes trone can honour

As writeth Iohan, in the apocalypse

Her heer, that was owndy and cryps

As burned golde shone, as for to se

And sothe to tellen, also she

Had also fell standyng eares

And tonges, as on a beest ben heares

And on her fete woxen sawe I

Partriches wynges redily $\left(1360-1392 ; \mathrm{B}^{\mathrm{ri}}{ }^{\mathrm{r}-\mathrm{v}}\right)$

This description only fits the woodcut insofar as it depicts a large female creature. Gillespie's claim that "she holds out two banners beneath the 'sterres seven' that light her court" is misleading. These are not clearly banners, and the "stares seuyn" mentioned in the text are either the septentriones in Ursa Major or the seven classical planets; either way, the emphasis in Chaucer's text is simply on how tall Fame is. The woodcut gives seven stars over each of the woman's hands, and these stars are configured in ways that do not at all resemble the Big Dipper or the seven planets. More importantly, there are no warring armies of beast-men in Chaucer's description, and the only possible connection to the seven-headed apocalyptic beast comes in a simile-Fame's eyes are as many as the number of feathers that were on the four beasts in the Apocalypse that surround God's throne - and even these are a youth, a lion, an ox, and an eagle, not the seven- 
headed dragon of Revelation. ${ }^{41}$ The illustration on the woodcut simply does not fit the action of The House of Fame.

Saying what exactly the title page woodcut does illustrate is much more difficult. The warring armies, the seven-headed dragon, even the large female figure (either as the Whore of Babylon or the Woman clothed with the sun) all point to the Book of Revelation as its source, but nowhere in Revelation does this exact scene occur. Poring over illustrations of Revelation produced in the period, one finds not a single direct source or analogue for this scene; many of the individual elements are present, but never presented in exactly this manner. ${ }^{42} \mathrm{I}$ find it highly unlikely that Pynson would have commissioned this cut specifically for his House of Fame. In Pynson's editions of the much more unified and popular Canterbury Tales and Troilus and Criseyde, no original woodcuts were used; the Pynson house reused woodcuts or simply copied already-existing blocks. The origin of this odd image is most likely a work about the end times that has since been lost, and this conclusion is suggested by later woodcuts in this edition. Pynson's illustration for The Parliament of Fowles-a collection of birds congregated together in a rain of blood-while apt enough for the story, is not original; it is taken from a Vérard copy of The Art of Good Living and Good Dying (STC 791), in the section on the fifteen signs of the end times depicting "The .v. tokynyng shalbe quen the herbes et trees shal sweyt reed vater as blood" (cc.ivvv) and "Et in the self day byrdys of the hewyn shal gaddyr to gyddyr the qwych shal cry and weyp withowt eytyng or drynkyng in ony mayneyr that may be" $\left(\mathrm{cc.} \mathrm{v}^{\mathrm{r}}\right)$

\footnotetext{
${ }^{41}$ The text itself seems to be rather ambiguous here: Fame or Rumor is often depicted visually as having wings, covered with eyes. See, for example, Enea Vico's engraving of Fame in The Illustrated Bartsch, Vol. 30, ID number 75 (312), in which a winged Fame, covered with eyes, blows a trumpet.

${ }^{42}$ Given the fact that Pynson copied woodcuts found in French and Dutch books, and not wishing to neglect possible manuscript parallels in trying to find a source or analogue for this image, I consulted the following works: J.A.A. M. Biemans, Middelnederlandse bijbelhandschriften, Corpus Sacrae Scripturae Neerlandicae Medii Aevi, Catologus, (Leiden: Brill, 1984); Laurence Riviére Ciavaldini, Imaginaires de l'Apocalypse (Grenoble et Lausanne: Cths: Institut national d'histoire de l'art, 2007); Syndey Carlyle Cockerell, ed., Some German Woodcuts of the Fifteenth Century (Kelmscott Press d. 26); William Martin Conway, The Woodcutters of the Netherlands in the Fifteenth Century (Cambridge: Cambridge University Press, 1884); Campbell Dodgson, English Woodcuts of the Fifteenth Century, in the series Einblattdrucke des Fünfzehnten Jahrhunderts, Herausgegeben von Paul Heitz, 88. Band. (Strasbourg, J.H. Ed. Heitz:, 1936); Koen Goudriaan, Paul Abels, Nico Habermehl, en Bart Rosier, Een drukker zoekt publiek: Gheraert Leeu te Gouda 1477-1484 (Delft: Uitgeverij Eburon, 1993); Edward Hodnett, English Woodcuts, 1480-1535 (Oxford: Oxford University Press, 1935); M.E. Kronenberg, Een der eerste Noord-Nederlandse drukkers Gerard Leeu: Gouda 1477-1484 (Gouda: Nv Drukkerij Kock \& Knuttel, Januari, 1956); Walter S. Melion and James Clifton, eds., Scripture for the Eyes: Bible Illustration in Netherlandish Prints of the Sixteenth Century (London: D. Giles Limited and New York: Museum of Biblical Art, 2009); Wouter Nijhoff, med medewerking van M.E. Kronenberg, Nederlandische Bibliographie van 1500 tot 1540 (S-Gravenhage: Martinus Nijhoff, 1919); Natasha F.H. O'Hear, Contrasting Images of the Book of Revelation in Late Medieval and Early Modern Art: A Case Study in Visual Exegesis (Oxford: Oxford University Press, 2011); M.J. Shrelten, with forward by M.J. Freidlaender, Dutch and Flemish Woodcuts of the Fifteenth Century (London: Ernest Benn, LTD, 1925); Walter L. Strauss, founding editor, and John T. Spike, general editor, The Illustrated Bartsch, Volumes 80-84 (New York: Abaris, 1978-); John MacFarlane, Antoine Vérard, Illustrated Monographs issued by the Bibliographical Society: No. VII (London: Chiswick Press, 1900 for 1899); as well as two books containing Vérard woodcuts in the library of All Souls College, Oxford: La Bible en franoys (Lyons, 1531) and Le premier (et le second) volumes de la bible historiee (Paris, 1499). While certain generic features from Revelation (the Whore of Babylon, the Seven-Headed Dragon, etc.) appear, none of these collections or early printed books showed any strong parallels to the Pynson House of Fame woodcut.
} 
(Fig. 5). ${ }^{43}$ This fact is not noted by Hodnett. ${ }^{44}$ Pynson clearly had access to apocalyptic treatises, and used a scene from one of them as an appropriate title page illustration for The Parliament of Fowles. If one ignores the (bloody) rain, the collection of birds is a well-chosen introduction to the work. Of the other three illustrations in this anthology, two of them - a Lady with an attendant before $L a$ belle dame sans merci and Mary Magdalene before her Complaint-are taken from other works, while the third-Dido stabbing herself-is not found elsewhere, but is a common enough scene, and sources abound. ${ }^{45}$ Just as the rest of the illustrations in his catalogue of Chaucerian works, these images were taken from elsewhere. But why take this image for the anthology? True there is a large queen in the center and a throng of people beneath her, but otherwise the warring beast-armies and seven-headed dragon make it an odd choice for the House of Fame, for the apocalyptic resonances overwhelm any apparent suitability.

The most satisfying answer is found in the central reading principle in this anthology. If there is one theme that is struck continually throughout the contents of this edition, it is the difficult, often confusing nature of human life; the proper response to this confusion, over and again, is a call to embrace virtue. The moral proverbs in the center and at the end of this anthology are more than mere filler: they are the instructions for how to read it. Readers of the first three items in this anthology are faced with many problems: fortune and fame are fickle and language is imperfect (The House of Fame), judging lovers is difficult (The Parliament of Fowles), and romantic love is often unrequited (La Belle Dame Sans Merci). Debates are unresolved or end in death. The proper answer to the mutability of the world is the predictably Boethian response of clinging to virtue. Even the "envoy limprimeur" to La Belle Dame Sans Merci simply stresses the importance of abjuring disordered love by ordering one's loves towards marriage and God:

Wherefore ye gentyll people yong and olde

Men or women what soeuer ye be

To loue I counsayle you be nat to bolde

Excepte it be ordred to suche degree

As concerneth spousayle in honeste

\footnotetext{
${ }^{43}$ HEW 5.11.8, Houghton Library, Harvard University; image used with permission.

${ }^{44}$ Hodnett gives this woodcut as number 1502, describing it as follows: "Nine fowls, including (L) a cock, (c) an owl, (a) two peacocks. Two trees. Nine plants. Objects falling through the air" (347).

${ }^{45}$ The La belle dame sans merci woodcut is number 1944 in Hodnett, described: “(L) A girl. (c) A lady holding a flower. Stone wall. Floor of rectangular tiles divided diagonally into black and white triangles. Arch frame with black and white spandrels" (389). The Mary Madgalene woodcut is number 1326: "Mary Magdalen, nimbed, facing slightly left, the box of ointment in her right hand"; the iconography used is very common, found in many books of hours (319). Dido is number 1494: "(L) A bonfire. (RC) A woman thrusting herself on the point of a sword, her left hand raised. (back LC to R) A city" (345) Hodnett notes that this Dido image was "described from a hand-drawn facsimile in L. copy" (345), but the Dido and Aeneas story was so common that finding a pre-existing illustration to copy would presumably not have been a problem for Pynson's house. Comparing the scene with contemporary depictions of Dido, Anne E.B. Coldiron conjectures that the woodcut was created for this edition in her English Printing, Verse Translation, and the Battle of the Sexes, 1476-1557, Women and Gender in the Early Modern World (Burlington, VT and Surrey England: Ashgate, 2009). This move would, however, break with Pynson's clearly established practice of recycling woodcuts for literally every other illustration in his 1526 editions, and it is far more likely that the image was simply copied or reused from a book that has not survived.
} 
Ye if ye wyll in feruent loue excel

Loue god aboue althing and than do ye well (E.iii ${ }^{v}$ )

The collections of moral proverbs speak for themselves as instructions in lives of virtue, and the complaints of Mary Magdalene and Dido serve as clear examples of rightly ordered love and wrongly ordered love; the reader is to love like St. Mary Magdalene, not like Dido. Mary and Dido in this anthology actually have strong parallels to one another: both are mourning their departed lovers (Christ and Aeneas), both have suicidal passages (although Dido is the only one who actually commits it), and both end with images of the speaker dying, serving as relics for pilgrims, with notable epitaphs. The difference between the two, of course, is that Mary Magdalene did, ultimately, order herself in Christian virtue while Dido did not.

Given the contents, the title-page illustration becomes more understandable as an intelligent choice for this anthology. The presence of the beast of the apocalypse suggests that the battle depicted is between good and evil. Though somewhat ambiguous, it is probable that "good" is on the queen's right; in addition to this side not being "sinister," the animal on the right is a lion, a traditionally nobler beast than a wolf. This noble lion stabs the wolf-like beast on the lady's left, and it is not a stretch to read this action as the triumph of good over evil. ${ }^{46}$ This battle between good and evil, the moral dimension of human life, is constantly highlighted in this anthology; humans can choose between good and evil, virtue and vice, and our ultimate happiness depends on this choice. Despite the importance of this conflict, identifying what is truly good may be difficult, as The House of Fame shows. The fact that the queen in the woodcut holds identical squares (possibly books) over the opposing armies visually depicts this difficulty. What Chaucer provides, according to this edition, is some kind of clarity: Julia Boffey has noted that the Chaucerian works in this edition work together to exhort the reader to Christian virtue ${ }^{47}$ and Pynson's treatment of them in this edition confirms her reading. Complex and beautiful, the Pynson House of Fame thus serves to promote the vision of Chaucer as a poet of moral sentence as an antidote to the vicissitudes of the world.

Ultimately, Pynson's House of Fame anthology is as much of an homage to Caxton as is his Canterbury Tales. Caxton printed both a Parliament of Fowles in 1477 (STC 5091) and a House of Fame in 1483 (STC 5087); the Parliament was printed as an anthology alongside works of moral content: "Treatise of Scoggan," "The Good Counsel of Chaucer," "Fly the Press," "Complaint to Fortune," and "Envoy to Skegan." Pynson simply combined the structure of the two Caxton editions into one: a House of Fame, followed by a Parliament of Fowls anthology

\footnotetext{
${ }^{46}$ The wolf-beast in this illustration may refer to the false prophet mentioned in Revelation 16:13, 19:20, and 20:10. Although he does not appear in sheep's clothing in this woodcut, the association between wolves and false prophets - authorized by Matthew 7:15 - makes this a likely reading. Furthermore, Revelation 5:5 refers to Christ as the Lion of Judah. Read with these Biblical texts in mind, the apocalyptic struggle between Christ and the false prophet looms large in this picture. I am grateful to Mark Rankin for pointing out this parallel. Additionally, the fact that the female figure treads on the dragon may identify her as the Woman clothed with the sun, though, again, this exact scene is found nowhere in The Book of Revelation.

${ }^{47}$ Julia Boffey, "Richard Pynson's Book of Fame and the Letter of Dido," Viator 19 (1988): 339$53,342-3$
} 
containing shorter Chaucerian works, largely of moral instruction. Of the items included, La belle dame sans merci clearly links itself to the Parliament: it is misattributed to Chaucer as the translator, and begins with a dreaming narrator similar to the one found in the Parliament of Fowles. The Letter of Dido to Eneas links clearly to The House of Fame, in which the Dido story is recounted in Book I, and its unnamed translator may be taken to be Chaucer, given the misattribution in La belle dame sans merci. As both Caxton's anthology and manuscript anthologies demonstrate, the moral proverbs, even when overtly attributed to Pizan or Lydgate, are a generic feature of such Chaucerian miscellanies. Even the apparent odd poem out - the Complaint of Mary Magdalene - is recognizable as a Chaucerian piece: in Chaucer's Retraction (printed for the last time in the Tudor era in Pynson's Tales of the same year), Chaucer mentions that he wrote books of saints' lives and devotional works, "other bokes / as of legends of sayntes" (Y.iiiv). A complaint (a genre favored by Chaucer) spoken in the persona of a major saint could reasonably be taken for an authentic work of Chaucer, particularly if it were found already anthologized with other Chaucerian poems. All of the items in Pynson's House of Fame anthology may be accounted for simply as parts of a traditional anthology of shorter Chaucerian works, and are presented to be read for moral instruction.

In the end, Pynson's editions of Chaucer produced in 1526 show themselves to embody the variety of reading and interpretive strategies applied to Chaucer's texts in Tudor England. On the one hand there is the clear presence already of a tradition of how Chaucer in print should look, found in Pynson's overtly Caxtonian Canterbury Tales and House of Fame anthology. On the other hand, Pynson is an innovator, and presents readers with a variety of reading strategies; the debate between de Worde's and Pynson's respective editions of Troilus and Criseyde is clear evidence of a multiplicity of interpretations. These innovations further seek to engage readers in active reading practices, whether those are discontinuous reading to glean authorial intent, continuous reading for universal principles, or commonplace reading for moral wisdom. This great variety of reading strategies becomes even more impressive when one considers the three Pynson editions bound together, as they are in all surviving book copies. While I have argued in this article that the editions deserve to be considered separately, their ability to be neatly bound together further highlights the impressive variety found in Chaucer's works. Not only has Chaucer written works in a great variety of genres, but these different genres call for a variety of ways of reading them, presenting Chaucer's works as inherently polysemous, rather than controlled by a single, authoritative way of reading (as Speght's "arguments" in his 1602 edition would attempt). Pynson's editions of Chaucer deserve to be considered some of the masterpieces of Chaucerian printing at the close of the Middle Ages. They are not as revolutionary as Caxton's or as monumental as the folio editions that would soon dominate sixteenth- and seventeenth-century readings of Chaucer, but they show an intelligent, careful attention to the texts, praising and selling Chaucer's works by making them as beautiful, accessible, and useful as possible to sixteenthcentury readers.

Mount St. Mary's University 
Appendix

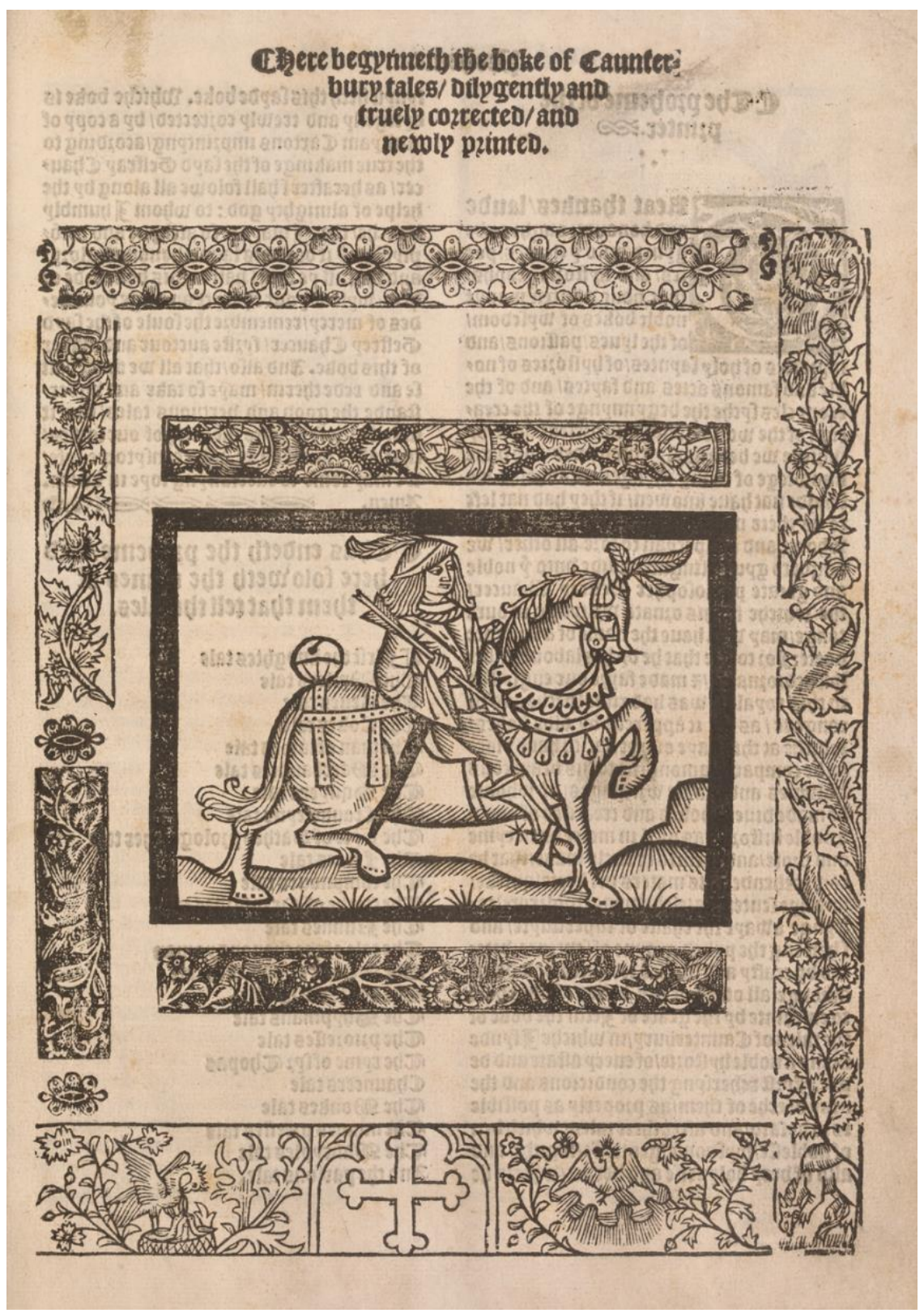

Figure 1. English. Title-Page of The Canterbury Tales, The Squire. Pynson, 1526. Boston, The Houghton Library, Harvard University, HEW 5.11.8. () Harvard University. Image used with permission. 


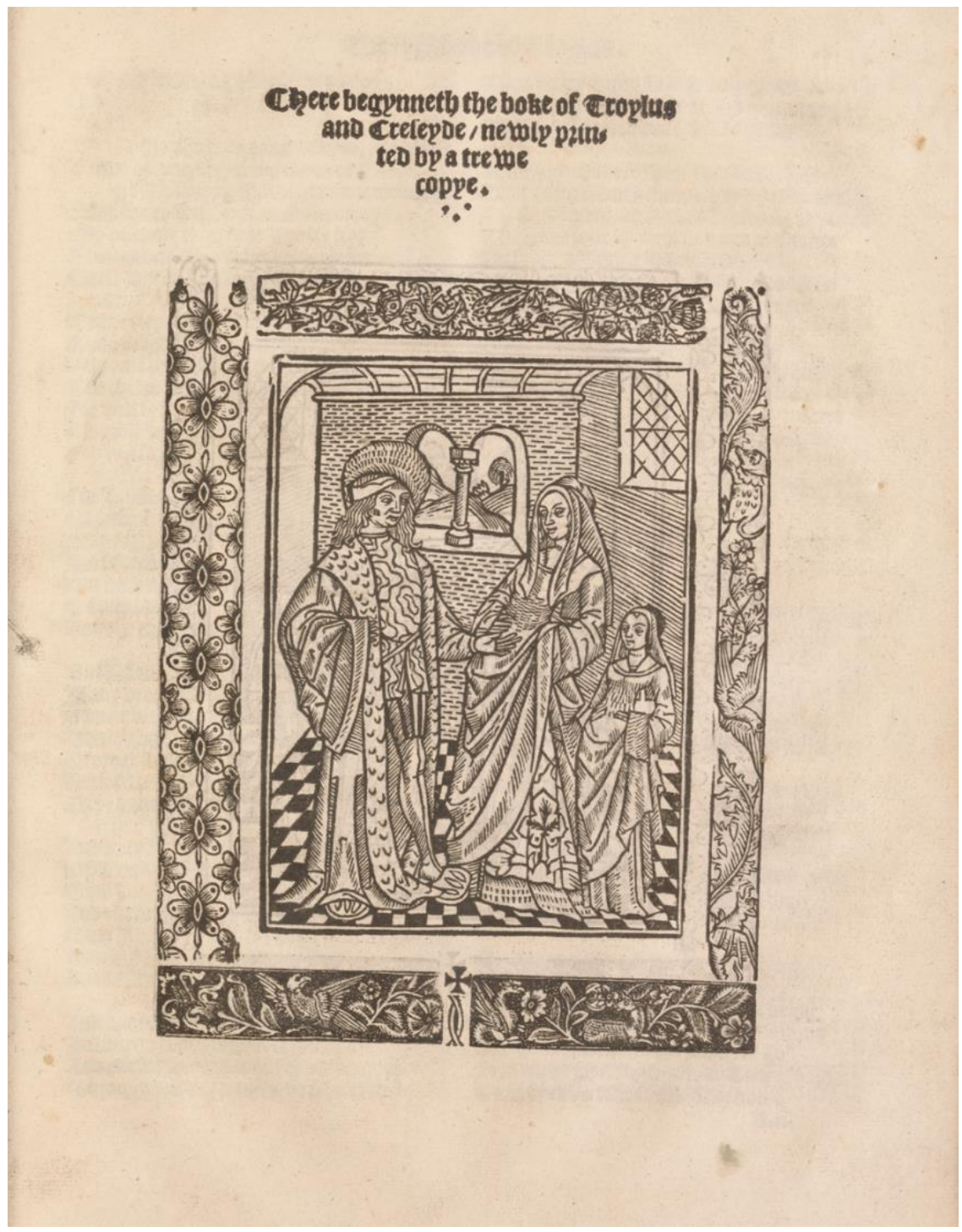

Figure 2. Title-Page of Troilus and Criseyde. Pynson, 1526. Boston, The Houghton Library, Harvard University, HEW 5.11.8. @ Harvard University. Image used with permission. 


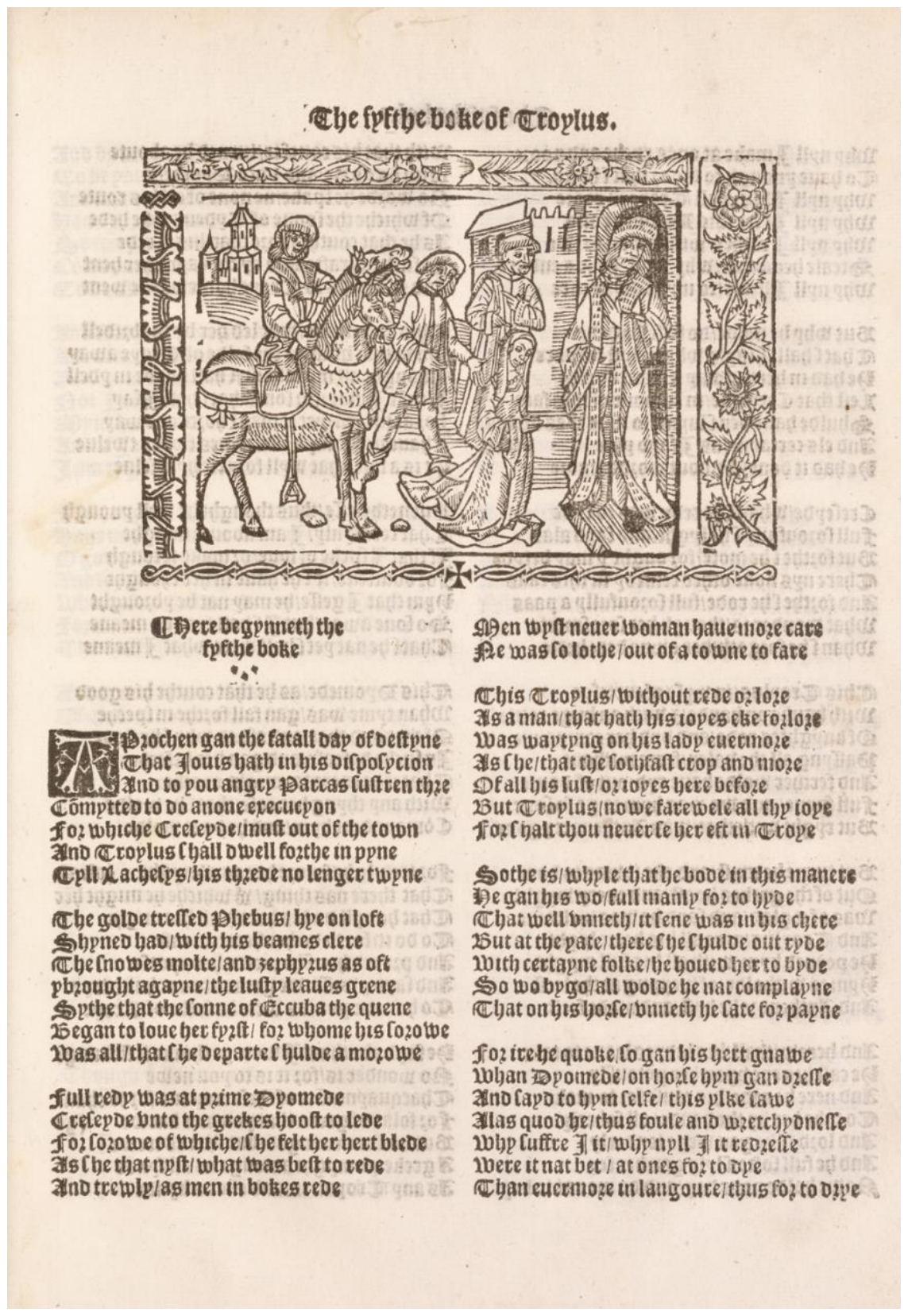

Figure 3. Opening of Book V of Troilus and Criseyde. Pynson, 1526. Boston, The Houghton Library, Harvard University, HEW 5.11.8, H.v. . ( ) Harvard University. Image used with permission. 


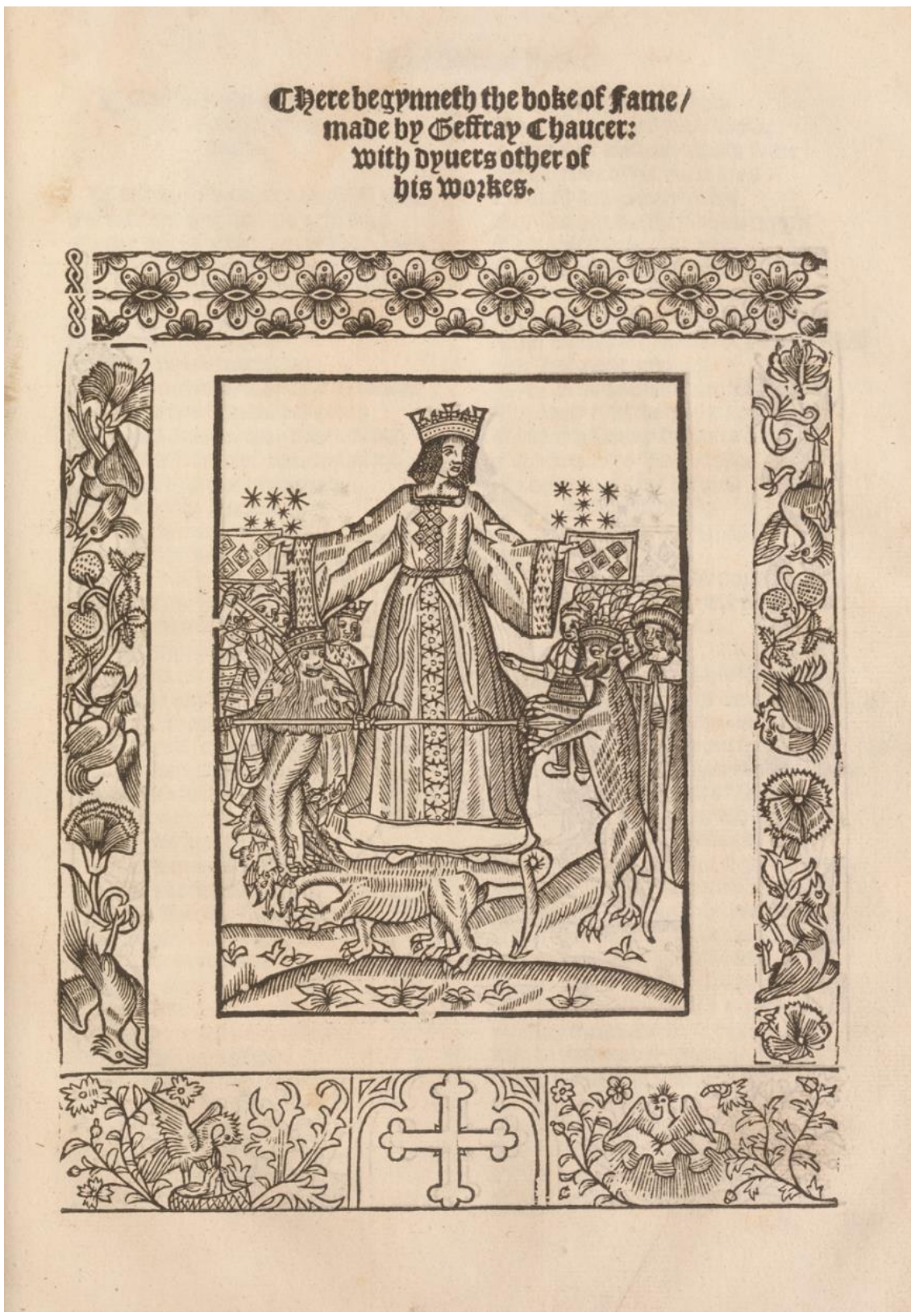

Figure 4. Title-Page of The House of Fame. Pynson, 1526. Boston, The Houghton Library, Harvard University, HEW 5.11.8. ( $)$ Harvard University. Image used with permission. 


\section{Bibliography}

Blake, Norman Francis. "William Caxton." In Authors of the Middle Ages: English Writers of the Late Middle Ages, edited by M.C. Seymour, 1-68. Brookfield, VT and Aldershot, Hants: Variorum, 1996.

Biemans, J.A.A. M. Middelnederlandse bijbelhandschriften. Corpus Sacrae Scripturae Neerlandicae Medii Aevi, Catologus. Leiden: Brill, 1984.

Boffey, Julia. "Richard Pynson's Book of Fame and the Letter of Dido." Viator 19 (1988): 339-53. https://doi.org/10.1484/J.VIATOR.2.301378

Boswell, Jackson Campbell and Sylvia Wallace Holton, Chaucer's Fame in England: STC Chauceriana 1475-1640. New York: Modern Language Association of America, 2004.

Bowen, Karen and Dirk Imhof. Christopher Plantin and Engraved Book Illustrations in Sixteenth-Century Europe. Cambridge: Cambridge University Press, 2008.

Carlson, David R. "Woodcut illustrations of the Canterbury Tales, 1483-1602" The Library, Series 6, 19, no. 1 (1997): 25-67. https://doi.org/10.1093/library/s6-19.1.25

Carruthers, Mary. The Experience of Beauty in the Middle Ages. Oxford: Oxford University Press, 2014. https://doi.org/10.1093/acprof:osobl/9780199590322.001.0001

—. The Book of Memory. Cambridge: Cambridge University Press, 2008.

—. "The Concept of Ductus, or Journeying Through a Work of Art." In Rhetoric Beyond Words: Delight and Persuasion in the Arts of the Middle Ages, edited by Mary Carruthers, 190-213. Cambridge: Cambridge University Press, 2010.

Carter, Harry. A View of Early Typography: Up to About 1600. Oxford: Clarendon Press, 1969.

Chaucer, Geoffrey. The Works 1532 with supplementary material from the Editions of 1542, 1561, 1598 and 1602. D.S. Brewer, ed. London: Scholar Press, 1978.

—. The Riverside Chaucer. Larry D. Benson, general editor. Oxford: Oxford University Press, 1987.

—. Troilus and Criseyde. Translated by George Philip Krapp. New York: Random House, 1932.

Ciavaldini, Laurence Riviére. Imaginaires de l'Apocalypse. Grenoble et Lausanne: Cths: Institut national d'histoire de l'art, 2007.

Cockerell, Syndey Carlyle, ed. Some German Woodcuts of the Fifteenth Century. Kelmscott Press d. 26: ND.

Coldiron, Anne E.B.. English Printing, Verse Translation, and the Battle of the Sexes, 1476-1557. Women and Gender in the Early Modern World. Burlington, VT and Surrey England: Ashgate, 2009.

Conway, William Martin. The Woodcutters of the Netherlands in the Fifteenth Century. Cambridge: Cambridge University Press, 1884. 
Cooper, Helen. "Poetic Fame." In Cultural Reformations: Medieval and Renaissance in Literary History, edited by B. Cummings and James Simpson. 361-78. Oxford: Oxford University Press, 2010.

- "Chaucerian Representation." In New Readings of Chaucer's Poetry, edited by Robert G. Benson and Susan J. Ridyard.7-30. D.S. Brewer, Cambridge, 2003.

Copeland, Rita. Pedagogy, Intellectuals, and Dissent in the Later Middle Ages: Lollardy and Ideas of Learning. Cambridge: Cambridge University Press, 2001. https://doi.org/10.1017/CBO9780511483264

Dane, Joseph A. Who is Buried in Chaucer's Tomb? Studies in the Reception of Chaucer's Book. East Lansing: Michigan State University Press, 1998.

Dane, Joseph and Alexandra Gillespie. "The Myth of the Cheap Quarto." In Tudor Books and Readers: Materiality and the Construction of Meaning, edited by John King, 25-45. Cambridge: Cambridge University Press, 2010.

Dodgson, Campbell. English Woodcuts of the Fifteenth Century. Einblattdrucke des Fünfzehnten Jahrhunderts, Herausgegeben von Paul Heitz, 88. Band. Strasbourg, J.H. Ed. Heitz, 1936.

Evenden, Elizabeth. Patents, Pictures and Patronage: John Day and the Tudor Book Trade. Farnham, U.K.: Ashgate Publishing, Ltd., 2008.

Foley, Robert A. Richard Pynson's Boke of Fame And its Non-Chaucerian Poems: A Study and an Edition. D.Phil. thesis, Jesus College, Oxford, 1987.

Forni, Kathleen Forni. The Chaucerian Apocrypha: A Counterfeit Canon. Gainesville, Tallahassee, et al: University of Florida Press, 2001.

- "Richard Pynson and the Stigma of the Chaucerian Apocrypha." The Chaucer Review 34, no. 4 (2000): 428-36. https://doi.org/10.1353/cr.2000.0004

Gillespie, Alexandra. Print Culture and the Medieval Author: Chaucer, Lydgate, and Their Books 1473-1557. Oxford English Monographs. Oxford: Oxford University Press, 2006.

Goudriaan, Koen, Paul Abels, Nico Habermehl, en Bart Rosier, Een drukker zoekt publiek: Gheraert Leeu te Gouda 1477-1484. Delft: Uitgeverij Eburon, 1993.

Hellinga, Lotte. William Caxton and Early Printing in England. London: British Library, 2010.

Hodnett, Edward. English Woodcuts, 1480-1535. Oxford: Oxford University Press, 1935.

The Illustrated Bartsch. Vol. 30, ID number 75 (312). Accessed on www.artstor.org, October 5, 2012.

The Illustrated Bartsch. Walter L. Strauss, founding editor; John T. Spike, general editor. Volumes 80-84. New York: Abaris, 1978-.

King, John. Foxe's Book of Martyrs and Early Print Culture. Cambridge: Cambridge University Press, 2006. https://doi.org/10.1017/CBO9780511483646

Krier, Theresa M. ed. Refiguring Chaucer in the Renaissance. Gainesville, FL: University Press of Florida, 1998. 
Kronenberg, M.E. Een der eerste Noord-Nederlandse drukkers Gerard Leeu: Gouda 1477-1484. Gouda: Nv Drukkerij Kock \& Knuttel, Januari, 1956.

Kuskin, William. Symbolic Caxton: Literary Culture and Print Capitalism. Notre Dame, IN: Notre Dame Press, 2008.

Lerer, Seth. Chaucer and His Readers: Imagining the Author in Late-Medieval England. Princeton, N.J.: Princeton University Press, 1993.

. "The Wiles of Woodcut: Wynkyn de Worde and the Early Tudor Reader." The Huntington Library Quarterly 59, no. 5 (1996): 381-403. https://doi.org/10.2307/3817694

MacFarlane, John. Antoine Vérard. Illustrated Monographs issued by the Bibliographical Society: No. VII. London: Chiswick Press, 1900 for 1899.

Machan, Tim William. "Speght's Works and the Invention of Chaucer." Text 8 (1995): 145-70.

Melion, Walter S. and James Clifton, eds. Scripture for the Eyes: Bible Illustration in Netherlandish Prints of the Sixteenth Century. London: D Giles Limited and New York: Museum of Biblical Art, 2009.

Miskimin, Alice. The Renaissance Chaucer. New Haven: Yale University Press, 1975.

Nijhoff, Wouter, med medewerking van M.E. Kronenberg, Nederlandische Bibliographie van 1500 tot 1540. S-Gravenhage: Martinus Nijhoff, 1919.

O'Hear, Natasha F.H. Contrasting Images of the Book of Revelation in Late Medieval and Early Modern Art: A Case Study in Visual Exegesis. Oxford: Oxford University Press, 2011. https://doi.org/10.1093/acprof:oso/9780199590100.001.0001

Reynolds, Susan. "Social Mentalities and the Cases of Medieval Scepticism." Transactions of the Royal Historical Society 1 (1991), 21-41. https://doi.org/10.2307/3679028

Robertson, D.W. A Preface to Chaucer. Princeton: Princeton University Press, 1962.

Ruggiers, Paul. ed. Editing Chaucer: The Great Tradition. Norman, OK: Pilgrim Press, 1984.

Scala, Elizabeth. Absent Narratives: Manuscript Textuality and Literary Structure in Late Medieval England. New York: Palgrave, 2002. https://doi.org/10.1057/9780230107564

- "Historicists and Their Discontents: Reading Psychoanalytically in Medieval Studies." Texas Studies in Literature and Language 44, no. 1 (Spring 2002), 108-31. https://doi.org/10.1353/tsl.2002.0006

Shrelten, M.J., with forward by M.J. Freidlaender. Dutch and Flemish Woodcuts of the Fifteenth Century. London: Ernest Benn, LTD, 1925.

Stallybrass, Peter. "Books and Scrolls: Navigating the Bible." In Books and Readers in Early Modern England: Material Studies, edited by Jennifer Anderson and Elizabeth Sauer, 42-79. Philadelphia: University of Pennsylvania Press, 2002. 
Stock, Brian. "The Self and Literary Experience in Late Antiquity and the Middle Ages." New Literary History 25, no. 4 (Autumn 1994), 839-52. https://doi.org/10.2307/469377

Wawn, Andrew. "Chaucer, The Ploughman's Tale and Reformation Propaganda: The Testimonies of Thomas Godfray and I Playne Piers." Bulletin of the John Rylands Library 56 (1973): 174-92.

https://doi.org/10.7227/BJRL.56.1.8 